\title{
The Effectiveness of Scaffolding Design in Training Writing Skills Physics Teaching Materials
}

\section{Parlindungan Sinaga}

Lecturer, Indonesia University of Education, Indonesia, psinaga@upi.edu

\section{Andi Suhandi}

Lecturer, Indonesia University of Education, Indonesia, andisuhandi@upi.edu

\section{Liliasari}

Lecturer, Indonesia University of Education, Indonesia, liliasari@upi.edu

Result of field studies showed low writing skill of teachers in teaching material. The root of the problem lies in their inability on translating description of teaching material into writing. This research focused on the effectiveness of scaffolding design. The scaffolding design was tested in the selected topics of physics courses for pre-service teachers through learning to write activity approach. The treatment effectiveness was determined by considering the effect size and normalized gain percentage, while the hypothesis was tested using "the Kruskal-Wallis test". The research results showed that scaffolding between the stages of planning and translating plans into text was effective in improving pre-service physics teachers' ability of writing physics teaching materials and was similarly effective in improving their conceptual understanding of the topics of electromagnetism, waves, and optics. Learning to write activity implemented in the course of physics with selected topics was effective in improving the ability of pre-service teachers in translating among different modes of representation and making multiple concept representations. The hypothesis test demonstrated that there was a significant difference in the abilities of writing teaching materials and conceptual understanding between experimental and control classes.

Keywords: Scaffolding, writing teaching materials, learning to write activity, preparation of physics teachers, concept representation

\section{INTRODUCTION}

The pre-service teachers' writing ability should be well-developed in order to help them write teaching materials of the subject they teach, report research results on the teaching and learning they conduct at schools, and guide their students in writing youth scientific works. Mastering the ability to write physics teaching materials, such as student 
worksheets, modules, lesson notes, practicum instructions, and textbooks is very important. It is expected that the content of physics teaching materials written by teachers for their students will be contextual and able to accommodate diverse students. However, feedbacks from college students, lecturers, and stakeholders demonstrated that many teachers do not have a good skill of writing teaching materials. This is proven by the fact that it is rare to find secondary school physics textbooks in Indonesia written by physics teachers. Physics textbooks for secondary school written by writers who are not physics teachers assume that readers have the same ability in understanding the main discussion explained; while in fact, they have dissimilar difficulties in learning physics. This phenomenon was evidenced in research (Nguyen \& Meltzer, 2003; Flores et al. 2004; and Beichner, 1994). Another drawback of physics textbooks written by nonteaching writers is the assumption that students' learning and living environments are the same, so that the content explanation is not contextual. Especially in Indonesia, which consists of thousands of islands with diverse vegetation and occupied by ethnic groups with diverse cultural and language backgrounds, it is very important for the physics textbooks to be contextual. The physics textbooks written contextually and able to accommodate students' diversity will only be produced by writers who teach physics.

In the curriculum of Indonesian teacher training institutes, the knowledge and skill of writing is only taught in the courses of English and Indonesian, with two credits for each course. Writing in the two courses is only for one sub-topic out of a number of topics taught. Hence, there is little support to help develop students' writing ability. Writing lesson in language courses gives more emphasis on how to write free writing or essays. Such a lesson is based on the general model of the processes involved in writing (Hayes \& Flower, 1980), and on the theory of writing expertise (Hayes \& Flower, 1986). Hayes and Flower model distinguishes among three basic writing processes: planning, translating plans into text, and reviewing. Planning includes the components of generating ideas, organization, and goal setting. Reviewing includes reading and editing as its components, while translating plans into text is a process of converting conceptual content into a linguistic form. Such knowledge and skill is not necessarily applicable in writing physics teaching materials. Although both are essentially essay writing, the one in language courses has different demands and emphases compared to writing physics teaching materials or other natural sciences.

The writing process model and writing strategy learned by pre-service teachers in the language courses appear to be less inadequate if applied in writing physics teaching materials. Therefore, pre-service teachers need help to develop their writing skills. Recent theories and research prove that such help is most effective if provided by lecturers of the respective discipline in the context of learning subject materials. The problem then is what kind of help needed by pre-service teachers so that they will have the skill of writing teaching materials. Experience shows that the difficulty students most frequently meet is in the process of translating from outline into a writing product. Even though students are able to make plans on what to write in the form of an outline, it is not necessary that they will be able to translate the plans into a writing product as a development from their outlines. In this research, a scaffolding design is tried between the stages of planning and translating plans into text in the model of Hayes and Flower. 
The writing skill developed for pre-service teachers in this research is writing teaching materials of physics. Writing physics teaching materials is different from writing essay in language lesson. The produced writing of physics teaching material should be easily understood by its readers who in this context are secondary school students contextual, and able to accommodate various difficulties experienced by students in understanding physics. The aim of the designed scaffolding, in addition to improve the ability of preservice teachers in translating plans into text, is to improve their knowledge and skills in representing physics concepts using various modes of representation. Hence, the designed scaffolding between the stages of planning and translating plans into text comprises of: Concept mapping, modes of concept representation, translation among different modes of representation, multiple representations, and multimodal representation.

The issue under research is how effective the designed scaffolding between the stages of planning and translating plans into text in Hayes and Flower model in learning to write activity in the program for pre-service physics teachers is. The problem is elaborated into the following research questions: 1) how effective is scaffolding between the stages of translating among modes of representation and multiple representations in learning to write activity approach? 2) How effective is the scaffolding design in improving physics conceptual understanding on the topics of electromagnetism and waves and optics? 3) How effective is the scaffolding design in improving the ability of writing physics teaching materials? 4) Is there any significant difference in the ability of writing physics teaching materials between the control and experimental classes? 5) Is there any significant difference in physics conceptual understanding between the control and experimental classes? The proposed hypotheses are: 1) There is no significant difference in the ability of writing teaching materials between experimental and control classes, and 2) there is no significant difference in physics conceptual understanding between the experimental and control classes.

The research is significant in order to bridge the gap between the low skill and ability of secondary school physics teachers in writing teaching materials and the needs for contextual and easily understood physics textbooks for students with diverse backgrounds. The bridging can be done by increasing support for the improvement of pre-service physics teachers' ability by means of extending opportunities for them to write in various subject matters (writing in the discipline). What the research contributes to the development of science is the development of Hayes \& Flower writing process model used in English course that can be applied in teaching writing teaching materials among pre-service teachers by using scaffolding in between the stages of planning and translating plans into text.

\section{METHOD}

Planning in learning to write activity is defined as making the writing of physics teaching materials for secondary school students on the topics of electromagnetism and waves and optics. The output is in the form of outline or description of the sub-topic. The planning stage in this research took two weeks, with 2 x 50 minutes for each week. The topics of electromagnetism and waves and optics were each divided into 17 sub- 
topics according to the number of students enrolling in the course. Each topic was distributed randomly to the students. Each student made description for one subtopic/topic according to what s/he got. The final product of this stage was description of the sub-topics in the form of an outline.

Pre-test on conceptual understanding of electromagnetism and waves and optics was given in the form of as many as 40 multiple choice questions, where the item validity of the instrument had the Pearson product-moment correlation coefficient $\left(\mathrm{r}_{\mathrm{xy}}\right)$ ranged from $0.4-0.7$, and its reliability determined by split half method as coefficient was $\left(\frac{r_{\mathbf{1 1}}}{\mathbf{2 2}}\right)=$ 0.886 . The pre-task writing of teaching material was done by assigning each student to write teaching materials in the form of conceptual content of a sub-topic. The task was to measure the initial ability of writing teaching materials and knowledge of how to write previously learned by students in language courses.

The second stage of the scaffolding is concept mapping (one week). The activity of concept mapping is intended to help students write the content of teaching materials hierarchically. This step is also a reflection of each student's content mastery as covered in the sub-topic assigned to him or her. First, the students should identify the concepts covered in the topic; secondly, they have to arrange the concepts into a diagram so that a concept map could be formed. In concept mapping, students should compose deductively, namely from the general concepts at the upper part to the less general concepts, to illustrations at the bottom part (Novak \& Gowin, 1984). The stage is aimed to train pre-service teachers to make teaching material writing that is well-arranged in terms of its content.

The next stage of the scaffolding is identifying modes of concept representation (a week long). At this stage, pre-service teachers in the research were introduced to learn various types of representation modes: text, picture, pictorial diagram, bar diagram, graph, mathematic (numerical) equation, table, photo, and the like. They were shown textbooks so that they could see how expert writers write physics teaching materials as well as the modes of representation they used. In this stage, pre-service teachers trained to represent the concepts they already arranged in their concept map by using certain modes of representation. In addition, they also learned to identify types of representation modes most appropriate to explain a physics concept based on the complexity of the concept and the backgrounds of its audience. Pre-test was given in order to find the students' initial understanding of translating among different modes of representation using an instrument in the form of 15 short/limited essay questions, where the validity coefficient $\left(r_{x y}\right)$ of each item was in the range of $0.45-0.67$, and its reliability coefficient determined by split half method $\left(\frac{r_{\mathbf{1 1}}}{\mathbf{2 2}}\right)=0.88$.

Translation among different modes of concept representation (two weeks). In this stage, students practice to be able to translate a mode of concept representation into another. This skill is important to be mastered by pre-service teachers because they will face students with diverse abilities in catching and understanding information, both one transmitted orally and in written and the one contained in written teaching materials. 
Thus, students have to be skilled in translating between modes of concept representation to accommodate students' difficulties in understanding physics concepts. Post-test on translation between modes of representation was given using the same instrument used in the pre-test.

Making multiple representations (two weeks). This scaffolding stage in the research was begun with pre-test to find the initial understanding of students on multiple representations. The instrument was in the form of limited essay questions consisting of 6 items with item validity coefficient $\left(\mathrm{r}_{\mathrm{xy}}\right)$ within a range of $0.4-0.74$ and reliability coefficient $\left(\frac{r_{\mathbf{1 1}}}{\mathbf{2 2}}\right)=0.84$. There was limitation in representing a concept clearly by only using one mode of representation. Secondary school students have dissimilar difficulties in understanding physics concepts represented by one type of representation mode. Hence, pre-service teachers need to be able to represent the same concept using various modes of representation; for example, the concept of Coulomb force represented by the modes of text, graph, numerical equation, and pictorial diagram. The pre-service teachers were assigned to make explanations of the concepts covered in the sub-topic to write using multiple representations, where a minimum of two representation modes should be used. This last stage was finalized with a post-test on multiple representations.

Making multimodal representation (four weeks). Multimodal representation is representing scientific research results or topic or sub-topic by integrating various types of representation modes (verbal and visual) in order to create a cohesive writing. Students are introduced to writing in science using multimodal representation. They practice to write teaching materials using multimodal representation. The students' writing in this research, in the form of written teaching materials for each sub-topic, was reviewed individually by peer review or expert review. The stage was finalized by giving post-tests on writing teaching materials and conceptual understanding of the topics of waves and optics and electromagnetism.

The research sample was determined purposively, and elective courses with selected physics topics with a number of 17 students were selected. The small class was chosen in order for the supervision of teaching material writing process to be more intensive. The control class consisted of two classes, namely 24 students taking the course of waves and optics and 22 those taking the course of electromagnetism in the same school year. The control class was given pre- and post-tests for conceptual problems. The task of writing teaching materials was given to each of the control classes at the end of the course. The writing of each of the students from both the control and experimental classes were then evaluated. The assessment was adapted from a rubric for writing evaluation made by Hand et al (2009). The aspects assessed were: concept correctness and clarity, accuracy of selecting representation mode and its integration into writing, the breadth and depth of topic explanation, conceptual hierarchy and writing organization, clarity of main idea's description in writing, writing convention and punctuation, and the ability to influence audience in writing. The data were gathered using the instruments of tests, semi-structured interview and questionnaires, and tasks. The effectiveness of scaffolding was determined by finding the effect size, where the 
formula used to calculate it was the one put forward by Coe (2000), and this formula was interpreted using Cohen criteria (1969). To determine the improvement of writing ability and conceptual understanding, the normalized average gain calculation was used, which was then interpreted using Hake's criteria (1999). Meanwhile, to test the hypothesis, non-parametric test, namely the Kruskal-Wallis test, was employed (Minium, 1993).

\section{FINDINGS}

The Effectiveness of Scaffolding in Improving Conceptual Understanding

Table 1: The normalized gain of conceptual understanding

\begin{tabular}{llll}
\hline Class & $\langle$ pretest $\rangle$ & $\langle$ post test $\rangle$ & $\%\langle g\rangle$ \\
\hline Experimental & 34.5 & 60.5 & 39.6 (medium) \\
\hline Controll & 32.0 & 52.0 & 29.0 (low) \\
\hline
\end{tabular}

The effect size of treatment in improving students' conceptual understanding

It was found that the mean gain of the experimental class was 27.12, with a standard deviation of 9.73; while the mean gain of the control class was 22.94, with a standard deviation of 4.36 , so that the coefficient of effect size $d=0.59$, with a medium criterion. Based on the analysis, it was proven that the use of scaffolding between the stages of planning and translating plans into text in the writing model of Hayes and Flower was effective to improve physics conceptual understanding on the topic of electromagnetism and waves and optics.

\section{Hypothesis Test}

To prove that the improvement of physics conceptual understanding on the topic of electromagnetism and waves and optics was a result of treatment in the form of scaffolding, statistic test was conducted. The proposed hypothesis $\left(\mathrm{H}_{\mathrm{o}}\right)$ is that there is no significant difference in physics conceptual understanding on the topic of electromagnetism between the experimental and control classes. The calculation resulted in $\mathrm{H}_{\text {cal }}=1.95$; then the $\mathrm{H}_{\text {cal }}$ was consulted with the Chi Square $\left(\chi^{2}\right)$ distribution for $\alpha=$ 0.90, and $d f=1$ Table $\mathrm{J}$ in Appendiix $\mathrm{F}$ (Minium, 1993) gives $\chi_{\text {erit }}^{2}=0.016$. Hence, on the Chi Square distribution table, $\mathrm{H}_{\mathrm{cal}}$ is on the right hand side of $\chi_{\text {crit }}^{2}$, which means that $\mathrm{H}_{0}$ was rejected, or it can be concluded that there was a significant difference in physics conceptual understanding between the experimental class treated with the use of scaffolding between the stages of planning and translating plans into text in the writing model of Hayes and Flower and the control class treated with expository approach in its instruction.

The normalized gain and effect size of translation among modes of representation on the topic of waves and optics and electromagnetism are each shown on table 2 and table 3.

Table 2: The normalized gain of translating among different representation modes

\begin{tabular}{llll}
\hline Topic & $\langle$ pretest $\rangle$ & $\langle$ post test $\rangle$ & $\%\langle g\rangle$ \\
\hline Waves and optic & 40.5 & 55.4 & 25 (Low) \\
\hline Electromagnetism & 41.5 & 54.1 & 21 (Low) \\
\hline
\end{tabular}


Table 3: The Effect Size of translation among modes of representation

\begin{tabular}{llllll}
\hline Topic & $\langle$ preest $\rangle$ & $\langle$ posttest $\rangle$ & Pretest STDEV & Post test STDEV & $d$ \\
\hline Waves and Optic & 40.51 & 55.38 & 16.24 & 17.89 & 0.87 \\
\hline Electromagnetism & 37.85 & 49.94 & 15.91 & 13.06 & 0.85 \\
\hline
\end{tabular}

The normalized gain and effect size for the multiple representation stage on the topic of electromagnetism and waves and optics are shown on tables 4 and 5.

Table 4: The normalized gain of multiple representation

\begin{tabular}{llll}
\hline Topic & $\langle$ pretest $\rangle$ & $\langle$ post test $\rangle$ & $\%\langle g\rangle$ \\
\hline Waves and optic & 48.9 & 69,8 & 41 (Medium) \\
\hline Electromagnetism & 40.0 & 50.6 & 18 (Low) \\
\hline
\end{tabular}

Table 5: The Effect Size of multiple representation

\begin{tabular}{llllll}
\hline Topic & $\langle$ preest $\rangle$ & $\langle$ posttest $\rangle$ & Pretest STDEV & Post test STDEV & $d$ \\
\hline Waves and Optic & 48.95 & 69.76 & 20.61 & 22.13 & 0.97 \\
\hline Electromagnetism & 40,0 & 50.58 & 14.14 & 12.48 & 0.80 \\
\hline
\end{tabular}

The Effectiveness of scaffolding in improving writing teaching materials ability

The normalized gain and effect size of the ability to write teaching materials using multimodal representation are given on tables 6 and 7

Table 6: The normalized gain of ability to write teaching materials

\begin{tabular}{llll}
\hline Topic & $\langle$ pretest $\rangle$ & $\langle$ post test $\rangle$ & $\%\langle g\rangle$ \\
\hline Waves and optic & 42.60 & 83.0 & $70,40(\mathrm{High})$ \\
\hline Electromagnetism & 42.65 & 83.06 & 74.0 (High) \\
\hline
\end{tabular}

Table 7: The Effect Size of scaffolding in improving writing teaching materials ability

\begin{tabular}{llllll}
\hline Topic & $\langle$ Exp.C $\rangle$ & $\langle$ Cont.C $\rangle$ & Exp. STDEV & Cont. STDEV & $d$ \\
\hline Waves and Optic & 82.41 & 57.29 & 10.29 & 15.67 & 1.89 (high) \\
\hline Electromagnetism & 82.06 & 63.04 & 10.68 & 11.81 & 1.91 (high) \\
\hline
\end{tabular}

It can be inferred that the use of scaffolding between the stages of planning and translating plans into text in Hayes and Flower writing model had a high effectiveness in improving the ability of pre-service physics teachers in writing teaching materials.

\section{Hypothesis Test}

To prove that the improvement of ability to write physics teaching material was a result of treatment in the form of scaffolding, statistic test was conducted. The proposed hypothesis $\left(\mathrm{H}_{\mathrm{o}}\right)$ is that there is no significant difference in the ability to write physics teaching materials between the experimental and control classes. The ability to write physics teaching materials on the topic of waves and optics, it was shown that $\mathrm{H}_{\text {cal }}=$ 22.77. The value was compared to the $\mathrm{H}_{\text {crit }}$ on the Chi Square $\left(\chi^{2}\right)$ distribution for $\alpha=$ 0.005 , and $d f=1$ Table $\mathbf{J}$ in Appendix $\mathrm{F}$ (Minium, et al, 1993) gives $\mathrm{H}_{\text {crit }}=7.88$. Based on these data, it was found that $\mathrm{H}_{\text {cal }}>\mathrm{H}_{\text {crit }}$, which means that $\mathrm{H}_{\mathrm{o}}$ was rejected. The ability to write physics teaching materials on the topic of electromagnetism, it was demonstrated that $\mathrm{H}_{c a l}=19.74$. The value was compared to the $\mathrm{H}_{\text {crit }}$ on Chi Square $\left(\chi^{2}\right)$ 
distribution for $\alpha=0.005$, and $\mathrm{df}=1$ gives $\chi_{\text {crit }}^{2}=7.88$ was obtained. Hence, because on the Chi Square distribution table $\mathrm{H}_{\text {cal }}$ is on the right side of $\chi_{\text {crit }}^{2}=7.88, \mathrm{H}_{0}$ was rejected. Based on this statistical analysis, it can be concluded that there was a significant difference in the ability to write teaching materials on the subject of electromagnetism and waves and optics between students whose writing activities used scaffolding and those who used expository approach in their instruction and used knowledge of writing from language courses.

\section{DISCUSSION}

The improvement of conceptual understanding on the topics of electromagnetism and waves and optics among students who used scaffolding in their writing activities was an impact of the stages in the designed scaffolding. At the stage of concept mapping, students were asked to identify the concepts covered in the description of the topic they made. The identified concepts were mapped accordingly based on their hierarchies in the form of concept map. The process allowed for the reinforcement of physics conceptual understanding the students had already known well and the assimilation between the already learned concepts and the new ones. The improvement of conceptual understanding was made possible by support from the stage of representing a concept using a single mode of representation. The students represented a concept through a certain mode of representation, such as text (narration), so they should ineluctably reread textbooks when they were unsure of the knowledge they already had. It was not until they understood the concepts that the students would represent them using the most mastered modes of representation. The process allowed for reinforcement on conceptual understanding previously mastered by the students.

The stage of translating between modes of representation and multiple representations of concept allows for a quite significant contribution for the improvement of students' conceptual understanding. The making of multiple representations of concept also demands students to well understand the concept to be represented and master the ability to translate among representation modes. At this stage, students learn to represent the same concept using different modes of representation. For instance, the concept of wave refraction is represented using the modes of narration, mathematic equation, picture, and table. When they represent the concept of wave refraction using narration mode, they have to think of what information to deliver, how to deliver it in the forms of sentence arrangement, and whether their explanations will be easily understood by the reader. The same is true for other modes of representation; take for example the mode of table, students have to think of what to include in the table so that readers can directly see the relationship between variables in the concept of wave refraction. This stage will condition students to experience the iterative process between reading textbooks to gain clear understanding of the concepts learned and the process of representing the concepts using various modes of representation. Looking at the process, it can be inferred that the improvement of students' conceptual understanding in this research was to some extent resulted from the stages of multiple representation making and translating among modes of representations. This finding strengthens the previous empirical facts (Hinrichs, 
2004; Finkelstein, et al., 2005; Kohl, et al., 2007; Prain, et al., 2009; deLeone \& Gire, 2005; Rosengrant, et al., 2006; Rosengrant, et al., 2005; Kohl \& Finkelstein, 2005; Kohl et al., 2008).

The effectiveness of scaffolding in improving conceptual understanding could also be partially contributed by the stage of writing teaching materials using multimodal representation. At this stage, the pre-service teachers were assigned to write a description of a sub-topic on the topic of waves and optics and electromagnetism. The writing had to be arranged in such a way that it would be easily understood by secondary school students. The conditioning will make students think of how to arrange material description hierarchically, how to choose the most appropriate mode of representation for each of the concepts covered in the sub-topic, how to integrate various modes of representation selected in order to create a cohesive writing; it also makes them think of the breadth and depth of the sub-topic that has to be described to suit the secondary school students' needs, how to communicate with readers through their writing, and how to prevent their writing from misconceptions. The research results are paralleled to those on the use of multimodal representation combined with WTL activity on physics instruction (Hand et al. 2009; Atila, 2010).

The normalized gain for the domain of waves and optics was almost similar to that of electromagnetism, where both of them were at the low criterion. Seen from the characteristics of both domains, it is clear that the concepts covered in the topic of electromagnetism are more abstract than the ones in the topic of waves and optics. The results of questionnaires and interviews regarding translation among types of representation modes revealed that almost all students (87\%) stated that they sometimes experienced difficulties depending on whether they understood the concepts contained in the initial representation mode given. If they did not comprehend the concept, they would not have any idea to translate from one mode of representation to another. On the other hand, based on questionnaire results, another factor influencing the ability to translate between modes of representation of a certain concept demonstrated that the majority of students $(76 \%)$ said that they still experienced difficulties in selecting an intermodal representation. When the intermodal representation was not appropriate, the final representation mode previously aimed could be inappropriate.

Based on the initial representation modes, the ones used for the domain of electromagnetism were text (narration), picture, mathematic equation, pictorial diagram, free body diagram (FBD), and graphic. The mean normalized gain for the ability to translate from text mode (narration) to other modes of representation (pictorial diagram, graph, mathematic equation and table) was 26 , with a low criterion. Meanwhile, the normalized gain for the ability to translate from the representation mode of picture to other representation modes (text and pictorial diagram) was 30, with a medium criterion. For the ability to translate from the representation mode of mathematic equation into other modes of representation (text, pictorial diagram, graph, and picture), the mean normalized gain was 18 , with a low criterion. The ability to translate from the mode of pictorial diagram into other representation modes (text, mathematic equation, and picture), obtained the mean normalized gain of 19 with a low criterion. Next, the ability 
to translate from FBD mode of representation into other modes (text, mathematic equation) gained the mean normalized gain of 22 with a low criterion. Finally, the mean normalized gain for the ability of translating from the representation mode of graph into other representation modes (text, mathematic equation) was 23 with a low criterion.

Based on the research, it was found that for the domain of electromagnetism, the most difficult translation is that from mathematic equation into other modes of representation. The translation from mathematic equation mode into graph required a mediator, namely the representation mode of table. If the physics equation is simple, for example consisting of only two parameters, a table of the relationship between the two parameters can be directly made. When the equation contains a couple of parameters, the students should determine first which parameter is assumed to be constant and which one should be varied. Hence, several tables should be made, and as a consequence, there will be some graphs representing the equation. It was at this stage that most students still experienced difficulty in determining the independent and dependent variables of quite complex physics equation. Translating from the representation mode of mathematic equation to picture requires that the equation be analysed first, in terms of the relationship between parameters the equation contains. What follows is determining what to describe from the concept of physics law stated in the mathematic equation. In the case of Coulomb law for instance, the students should make a picture explaining how attractive or repulsive forces between two electric charges are inversely proportional to the square of the distance between the two charges and directly proportional to the amount of each electric charge. This representation mode of picture should be made in such a way that the audience can understand how one parameter connects to the other. The process needs cognitive engagement from the students, namely the understanding of the physics concept to be represented. If the concept is not grasped, it will be difficult to determine what to describe or illustrate from the concept.

The lowest level of translating among modes of representation on the domain of waves and optics was one of translating from the representation mode of graph into other modes of representation. In general, the research found that the ability to translate among modes of representation did not depend on the domain; in contrast, results from questionnaires and interviews revealed that it was the understanding of physics concepts to be represented that determined the ability. The research also proved that the most difficult translation for students was different for each domain. On the domain of electromagnetism, the most difficult translation among modes of representation was that from mathematic equation mode to other representation modes, while for the domain of waves and optics, the most difficult one was from representation mode of graph into other modes of representation. Translating from representation mode of graph into mathematic equation mode requires the skill of reading graph, which is finding information on what parameters are stated in the graph, and based on the curve shape determining the relationship between the parameters, whether it is directly proportional, inversely proportional, etc. Difficulties will arise when students still cannot read graphs and determine the relationship between parameters contained in the graph based on the curve shape. This fact could well be the reason why in this research the gained ability of 
translating from the representation mode of graph into other modes of representation was the lowest.

Research data demonstrated that, in addition to depend on the domain, the ability of making multiple representations of physics concept depended on physics concept understanding. This is in line with the previous research (Ainswort, 2006) which argued that even though external representation provides many benefits for students, there will be additional difficulties experienced by students. Students do not only have to understand the individual representation and its relationship to the domain, but also grasp the relationship among several representations. It is precisely because of these difficulties that students frequently ignore multiple representations and tend to use single representation. The questionnaires' and interviews' results on the making of multiple representations of concept given after the students had learned, practiced, and done tasks pertaining to making multiple representations of physics concepts, revealed that the majority of them expressed that in-depth understanding of the concepts of physics to be represented highly determined their ability in making multiple representations. They further revealed that each representation mode had its own difficulties.

Data analysis results showed that the pre-service teachers' ability of writing teaching materials improved in terms of knowledge and skills. The improvement of the ability to write teaching materials was significantly different between the students in the experimental class and those in the control class. The designed scaffolding between the stages of planning and translating plans into text was proved to be effective in improving the pre-service teachers' ability in writing physics teaching material. The improvement was ineluctably linked to the designed scaffolding between the stages of planning and translating plans into text in the writing model of Hayes and Flower. The designed scaffolding had proved that pre-service physics teachers were able to translate the outline of a sub-topic of waves and optics and electromagnetism into written teaching materials. Before arriving at the stage of multimodal representation of a topic or topic, the students were first introduced and taught about types of representation modes, multiple representations of concept, and translation among different modes of representation. Each student made planning to write teaching materials according to the sub-topic s/he got. The output of this planning stage was in the form of description or outline of a sub-topic. After identifying the concepts covered in a sub-topic and arranging them into concept map, the students were invited to think of how to rerepresent each of the concepts in order to be easily understood by secondary school students. At this stage, the pre-service or student teachers were introduced to various representation modes, followed by the assignment of representing a concept with a certain representation mode. Afterwards, a class discussion was held to see whether all information pertaining to the concept had been covered by the representation. At this stage, the students knew by direct experience that it was really difficult to explain a concept comprehensively by only using a single representation mode. The students were then introduced to multiple representations of concept, namely explaining the same concept using several representation modes. 
Nonetheless, to be able to make multiple representations of a concept requires the students to have the skills of translating among different modes of representation. The scaffolding stage had generated ideas among the students on how to translate outline into writing. However, the writing produced at this stage was still in the form of fragments of concepts' description covered in a sub-topic using multiple representations. Meanwhile, written physics teaching materials should fulfil the following criteria: The concepts should be clear and correct, the representation modes used to represent the concepts should be mutually completing so that the delivered information could be wellcomprehended by the reader, the concepts' explanation on the sub-topic should be arranged hierarchically, and the depth and breadth of the content should be suitable to the intended audience. Pre-service teachers should have the skills and knowledge of combining writing fragments into a cohesive writing that fulfils the criteria for the writing of physics teaching materials. To help them gain the skills, the next scaffolding stage to be given is multimodal representation. Multimodal representation is defined as explaining a topic or a sub-topic by integrating various modes of representation in order to make a cohesive writing. This stage is the chief process in encouraging students to be able to write teaching materials. They are provided with examples of writings of physics teaching materials using multimodal representation, both from physics textbooks or lecturer-made writing. Next, they make their own writing of teaching materials, present it before the class, and have their writing reviewed by their peers of lecturers. The input gained should be used to revise their draft and what follows is editing process.

The data gained from the research demonstrated that there was a significant difference in the quality of the writing of teaching materials produced by the students in the experimental class and those in the control class. This was corroborated by the calculation of effect size, showing a coefficient under the criterion of high effectiveness. Therefore, the designed scaffolding between the stages of planning and translating plans into text in the writing model of Hayes and Flower was proved to be effective in helping pre-service teachers write physics teaching materials.

\section{CONCLUSION}

Learning to write activity in the courses of physics with selected topics through the use of scaffolding designed in between the stages of planning and translating plans into text in the model of Hayes and Flower was effective in helping pre-service teachers be able to write physics teaching materials. The scaffolding was effective as well in improving their conceptual understanding of physics on the topics of electromagnetism and waves and optics. The use of scaffolding designed with the stages of concept mapping, translation among different modes of representation, multiple representations, and multimodal representation could improve the pre-service physics teachers' ability in writing teaching materials. The improvement was significantly different from the one experienced by the students who wrote their teaching materials without using the scaffolding. The improvement of the pre-service teachers' ability in writing physics teaching materials was supported by the effectiveness of learning to write activity implementation that could improve their ability in translating among different modes of representation and making multiple representations of concept. 
The implication of these results is that in order to support pre-service physics teachers to be good writers of physics teaching materials, they need to be provided with more opportunities to practice. The scaffolding in the writing model can be embedded in the course of study at teacher training institutes. Lecturers can teach the scaffolding stages while explaining the concepts of the topic covered in the course content. Selecting one sub-topic of a course content included in the curriculum of physics for secondary school to be made a writing assignment for pre-service teachers can also be done.

\section{REFERENCES}

Atila, M.E. et al. (2010). The effect of using multimodal representation within writing to learn activities on learning force and motion unit at the middle school setting. Journal of Turkish Science Education. .7(4) , 113-127.

Coe, R. (2000). What is an Effect Size?.A Guide for User. Draft version.

Cohen, J. (1969). Statistical Power Analysis for Behavioral Sciences. NY: Academiic Press

DeLeone, C. \& Gire, E. (2005). Edited by Heron, P., McCullough, L. \& Marx, J. Physics Education Research Conference Proceedings, Salt Lake City, UT, 45-48

Finkelstein, N. et.al. (2005). Phys. Rev. ST Phys. Educ. Res. 1, 010103

Glynn, S.M et al. (1982). Writing and revising persuasive documents: Cognitive demands. Journal of Educational Psychology, 74, 557-567.

Hinrichs,B., In edited by Marx, J., Heron, P \& Franklin, S (2004). Physics Education Research Conference Proceedings, Sacramento, CA, 2004, 117-120

Hayes, J and Flower,L. (1980). Identifying the organization of writing processes. In:Gregg, L. and Steinberg, E. (Eds.) .Cognitive processes in writing, (pp. 3-30). Hillsdale, NJ: Lawrence Erlbaum

Hayes, J. \& Flower, L. (1986). Writing research and the writer. American Psychologist 41,1106-1113.

Hayes, R.J. (2006). Handbook of Writing Research, Edited by MacArthur, C.A., Graham, S., \& Fitzgerald, J., Copyright (C) Guilford Publications.

Hand, B, et al (2009). Sequencing Embedded multimodal representation in writing to learn approach to the teaching electricity. Journal of Research in science Teaching, 46(3), 225-247.

Kohl, P.B., \& Finkelstein. N. (2005). Edited by Heron, P., McCullough, L \& Marx, J,. Physics Education Research Conference Proceedings, Salt Lake City, UT, 93-96.

Kohl, P.B. et al. (2007). Physical review special topics.Physics Education research, 3,010128 .

Kohl, P.B. et al. (2008). Physical review special topics, Physics Educational Research,4,010111. 
Minium, E.W. et al. (1993). Statistical Reasoning In Psychology and Education.( pp 483-484). John Wiley \& Sons, Inc

Novak, J.D., et al. (1984). Learning how to learn. New York: Cambridge University Press.

Prain,V. et al. (2009). Multiple representation in learning about evaporation. International journal of Science Education, .31(6),787-808.

Rosengrant, D et al. (2005). edited by Heron. P, . McCullough. L and Marx. J, Physics Education Research Conference Proceedings, Salt Lake City, UT, , 49-52.

Rosengrant, D, et al. (2006). National Association for Research in Science Teaching Proceedings, San Francisco, CA. 


\section{Turkish Abstract}

\section{Yapı Kurma Deseninin Fizik Öğretim Materyali Yazma Eğitiminde Etkililiği}

Alan araştırmalarının sonuçları material öğretiminde öğretmenlerin düşük bir yazma becerisi gösterdiğini belirtmektedir. Problemin kökü öğretmenlerin öğretim materyalinin açılamasını yazıya çevirmedeki yetersizlikte yatmaktadır. Bu çalışma yapı kurma (scaffolding) deseninin etkililiği üzerinde yoğunlaşmıştır. Bu desen aktivite yazmayı öğrenme yaklaşımı kullanılarak öğretmen adayları için seçilen fizik dersi konuları içinde test edilmiştir. Müdahalenin etkisi etki büyüklüğü ve yüzdeliklerle belirlenirken, hipotez Kruskal-Wallis testi kullanılarak test edilmiştir. Çalışmanın bulguları planlama ve planları metne çevirme aşamaları arasında yapı kurmanın fizik öğretmeni adaylarının fizik öğretimi materyali yazma becerilerini geliştirdiğini ve elektromanyetizm, dalgalar ve optik gibi konuların kavramsal anlaşılmasında da benzer olarak etkili olduğunu göstermiştir. Belirlenen konularla fizik dersinde uygulanan yazmayı öğrenme aktivitesi öğretmen adaylarının farklı temsil modellerinde çevirebilme ve çoklu kavram temsilleri yapabilme becerilerini geliştirmede etkili olduğu bulunmuştur. Hipotez testi deney ve kontrol grupları arasında öğretim materyali yazma ve kavramsal anlama becerilerinde anlamlı bir fark olduğunu göstermiştir.

Anahtar Kelimeler: Yapı kurma, öğretim materyali yazma, yazmayı öğrenme aktivitesi, fizik ögretmeni yetiştirme, kavram temsili

\section{French Abstract}

L'Efficacité de Design d'Échafaudage dans Formation de Matériels pédagogiques de Physique de Compétences d'Écriture

Le résultat d'études de terrain a montré bas la compétence d'écriture de professeurs dans le matériel pédagogique. La racine du problème se trouve dans leur incapacité en traduction de la description de matériel pédagogique dans l'écriture. Cette recherche s'est concentrée sur l'efficacité de design d'échafaudage. Le design d'échafaudage a été testé dans les sujets choisis de cours de physique pour des professeurs de pré service par l'apprentissage pour écrire l'approche d'activité. L'efficacité de traitement a été déterminée en considérant la taille d'effet et a normalisé le pourcentage de gain, tandis que l'hypothèse a été testée utilisant "le test de Kruskal-Wallis". Les résultats de recherche ont montré que l'échafaudage entre les étapes de planification et la traduction de plans dans le texte était effectif dans la capacité des professeurs de physique de pré service s'améliorant d'écrire des matériels pédagogiques de physique et était de la même façon effectif dans l'amélioration de leur compréhension conceptuelle des sujets d'électromagnétisme, des vagues et l'optique. L'apprentissage pour écrire l'activité mise en œuvre au cours de la physique avec des sujets choisis était effectif dans l'amélioration de la capacité de professeurs de pré service dans la traduction parmi les modes différents de représentation et la fabrication de représentations de concept multiples. Le test d'hypothèse démontré qu'il y avait une différence significative dans les capacités d'écrire des matériels pédagogiques et la compréhension conceptuelle entre expérimental et des classes de contrôle.

Mots-clés : l'Échafaudage, Écrivant des Matériels Pédagogiques, Apprenant à Écrire l'Activité, la Préparation de Professeurs de Physique, la Représentation de Concept

\section{Arabic Abstract}

العنوان: فعالية نظام السقالة في التدريب على مهارات الكتابة لمواد الفيزياء التعليمية. 


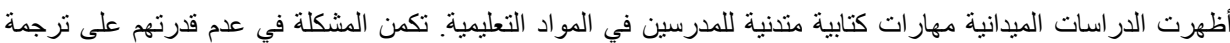

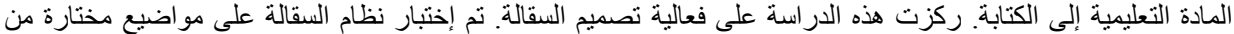

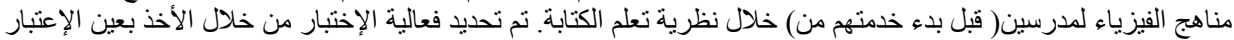

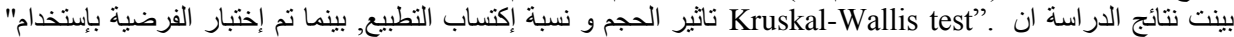

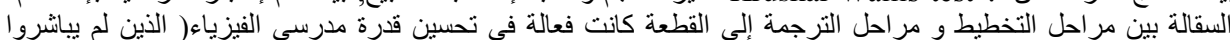

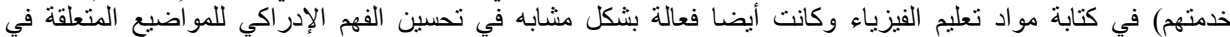

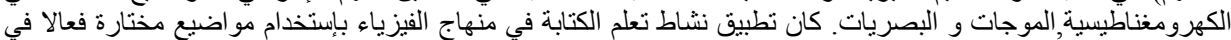

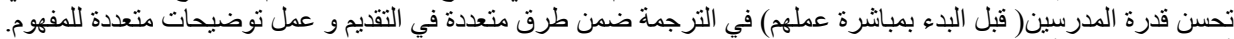

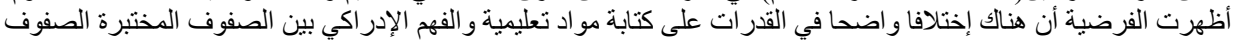
التي لم تخضع للاختبار.

كلمات مهمة: السقالة, مو اد لتعليم الكتابة, نشاط لتعليم الكتابة, تحظير مدرسين الفيزياء, توضيح المفهوم لم 